\title{
Relação entre a carga viral de HPV oncogênico determinada pelo método de captura híbrida e o diagnóstico citológico de lesões de alto grau
}

\author{
Association between high-risk human papillomavirus DNA load detected by hybrid capture II and high-grade \\ precursor lesions of cervical cancer in women
}

Siumara Tulio'; Luciane A. Pereira²; Fabiane B. Neves²; Álvaro Piazzetta Pinto

\begin{tabular}{l}
\multicolumn{1}{c|}{ Unitermos } \\
Papiloma virus humano (HPV) \\
Neoplasia intra-epitelial \\
Cervical (NIC) \\
Captura hibrida \\
Papanicolaou \\
DNA-Citoliq.
\end{tabular}

\section{resumo}

Introdução: O papilomavírus humano (HPV) é o principal fator de risco para as neoplasias intra-epiteliais cervicais (NIC) e o câncer cervical. Objetivo: O objetivo deste estudo é avaliar se há associação entre a carga viral de HPV oncogênico (alto risco), determinada por meio do teste molecular captura híbrida II (CH II), e o diagnóstico de lesões de alto grau (NIC II/III). Material e métodos: Foram analisadas 982 amostras cervicovaginais de exames ginecológicos de rotina, obtidas pelos métodos Papanicolaou convencional e/ou citologia em base líquida (DNA-Citoliq-Digene). Os resultados foram confirmados utilizando-se o método de captura híbrida (CH [Digene]) para detecção de DNA/HPV de alto grau. Os resultados com valor $\geq 1 \mathrm{pg} / \mathrm{ml}$ foram considerados positivos, e esses foram divididos em dois grupos: 1 . carga viral < $100 \mathrm{pg} / \mathrm{ml}$, e 2 . carga viral $\geq 100 \mathrm{pg} / \mathrm{ml}$. Resultados: Dos 210 (21,4\%) casos diagnosticados como NIC I, $152(72,4 \%)$ foram positivos para HPV de alto risco por CH II. Desses, $101(66,4 \%)$ apresentaram carga viral $\geq 100 \mathrm{pg} / \mathrm{ml}$. O diagnóstico de NIC II ou III foi confirmado por $\mathrm{CH}$ II de alto risco em 86 $(43,6 \%)$ casos, contudo, entre esses, em $53(61,6 \%)$ a carga viral detectada foi $\geq 100$ pg/ml. Discussão e conclusão: Nossos resultados demonstram que há uma clara associação entre o valor da carga viral determinada pelo método CH II (versão 1) e o grau das lesões precursoras de câncer. Pacientes com carga viral superior a $100 \mu \mathrm{g} / \mathrm{ml}$ devem ser monitoradas periodicamente.

\section{abstract}

Introduction: Infection with oncogenic human papilloma virus (HPV) has been established as the main etiologic agent for cervical cancer and of cervical intraepithelial neoplasia (CIN). Objective: To determine the association between viral loads of the high risk HPV using the hybrid capture II (HC II) system and CIN lesion stage.

Material and method: A total of 982 women with diagnosis of negative or of CIN I-III with Pap or liquid-based cytology (DNA-Citoliq-Digene) were included. HC II testing was used to detected HPV DNA. Viral load was measured expressed as relative lights unit (RLU) ratio. RLU ratios were categorized for analysis into three groups: negative (<1 pg/ml); positive with low viral load $(<100 \mathrm{pg} / \mathrm{ml})$; positive with high viral load $(\geq 100 \mathrm{pg} / \mathrm{ml})$. Results: A total of 152 (72.4\%) of 210 (21.4\%) patients with CIN II, 53 (61.6\%) of 86 (43.6\%) with CIN II-III were positive for HPV DNA, the higher the viral load ( $\geq 100 \mathrm{pg} / \mathrm{ml}$ ) were observed in 101 (66.4\%) and 53 (61.6\%) patients with CIN I or CIN II-III, respectively. Discussion and conclusions: Our results suggest a clear association between viral load HPV DNA determined by HC II (version 1) assay and CIN stage. We concluded that the high viral load has a clinical importance for the management of patients with CIN. key words

Human papillomavirus

Cervical intraepithelial

neoplasia (CIN)

Hybrid capture

Papanicolaou

DNA-Citoliq

1. Bioquímica do Laboratório de Citopatologia e Anatomia Patológica Annalab.

2. Alunas do curso de Especialização em Biologia Molecular do Centro Universitário Positivo (UnicenP).

3. Médico patologista do Laboratório Annalab. 


\section{Introdução}

Conhecidas desde a antiguidade, as infecções genitais por papilomavírus humano (HPV) começaram a chamar a atenção a partir da década de 1980, quando as lesões virais foram correlacionadas com o câncer de colo uterino. O câncer de colo uterino é o segundo tipo de câncer mais comum em mulheres no mundo. Aproximadamente $80 \%$ dos casos ocorrem em países em desenvolvimento, sendo pouco freqüentes antes dos 20 anos de idade ${ }^{(3)}$. O HPV é o principal fator de risco para neoplasias intra-epiteliais cervicais (NICs) e câncer cervical ${ }^{(9,17,18)}$. Entre os mais de 100 tipos de HPV identificados, nem todos são oncogênicos. No entanto, em $99,7 \%$ dos casos de carcinomas cervicais há presença de um ou mais desses tipos de HPV (alto risco ou oncogênicos): $16,18,31,33,35,39,45,51,52,56$, $58,59,66$ e $68^{(18)}$.

O método mais simples para prevenção do câncer cervical é o Papanicolaou. Entretanto, nas últimas décadas, vários estudos têm apontado para índices não-ideais de sensibilidade do preparado convencional, com variação entre 50\%-60\%(1). Além disso, há dúvidas sobre a utilização do teste como a única forma de acompanhamento de mulheres com células escamosas atípicas (ASCs). Recentemente, a citologia em base líquida começou a ser utilizada, objetivando maximizar a sensibilidade do teste citopatológico e permitir a realização de testes biomoleculares a partir da mesma amostra coletada para a análise morfológica.

O teste molecular de captura híbrida II ( $\mathrm{CH}$ II) para HPV é capaz de detectar o DNA de 18 tipos virais que mais comumente infectam o trato anogenital (masculino e feminino), sendo esses divididos em grupos de baixo risco (A) e alto risco (B). É um teste quantitativo e o único aprovado pela Agência Nacional de Vigilância Sanitária (ANVISA) para diagnóstico de HPV. Em comparação com o método da reação em cadeia da polimerase (PCR), a CH II demonstra sensibilidade de $91,7 \%$ e especificidade de $95,4 \%{ }^{(4)}$. Como o risco de câncer cervical invasivo na mulher está diretamente relacionado à presença de HPV de alto risco (B), a pesquisa desses tipos virais por meio de métodos moleculares tem sido extremamente útil para o acompanhamento de mulheres com alterações citológicas. A maioria das infecções por HPV é transitória e, aproximadamente, 70\% delas desaparecem no período de um ano ${ }^{(9)}$.

A repetição de exames citológicos em intervalos regulares, pelo método convencional ou em base líquida, bem como a realização de análise colposcópica imediata, exames de DNA do HPV para pesquisa dos tipos de alto risco e/ou a combinação de um exame citológico cervical com outro método complementar, são práticas amplamente utilizadas em vários países para acompanhamento de mulheres com $\operatorname{ASC}(2,5,8,15)$.

Este estudo objetivou avaliar se há associação entre a carga viral de HPV oncogênico (alto risco), determinada por meio do teste molecular $\mathrm{CH}$ II (versão 1), e o diagnóstico de lesões de alto grau (NIC II/III) pelos métodos citológicos Papanicolaou convencional e em base líquida.

\section{Material e métodos}

\section{População estudada}

Neste estudo incluímos 982 amostras cervicovaginais de exames ginecológicos de rotina, de mulheres com idades variando entre 16 e 67 anos, analisadas no período de janeiro de 2001 a setembro de 2004 no laboratório Annalab de Curitiba (PR).

\section{Citologia}

As amostras citológicas foram obtidas pelos métodos Papanicolaou convencional ou por citologia em base líquida (DNA-Citoliq-Digene). Os diagnósticos foram realizados utilizando a nomenclatura baseada no sistema Bethesda 2001 e na Sociedade Brasileira de Citopatologia (SBC). Nas lâminas utilizadas para este estudo foram observadas as seguintes alterações morfológicas:

- células escamosas atípicas de significado indeterminado (ASCUS);

- NIC (graus I, II ou III).

Devido a grande dificuldade em estabelecer o diagnóstico citológico diferencial entre as lesões de grau II e III, incluímos as mulheres com NICs II e III no mesmo grupo.

\section{Teste para DNA/HPV}

Utilizou-se o método de CH II (versão 1 [Digene]) para detecção de DNA/HPV de alto risco (tipos 16, 18, 31, 33, $35,39,45,51,52,56,58,59$ e 68), comumente associados com neoplasia intra-epitelial de alto grau e câncer cervical.

A carga viral foi determinada por meio da quantificação da emissão de luz e expressa como relação (amostra/controle positivo) da unidade de luz relativa (RLU). As amostras com relação $\mathrm{RLU}<1 \mathrm{pg} / \mathrm{ml}$ foram consideradas negativas. 
Os resultados com valor $\geq 1 \mathrm{pg} / \mathrm{ml}$ foram considerados positivos, e esses foram divididos em dois grupos:

- carga viral < $100 \mathrm{pg} / \mathrm{ml}$;

- carga viral $\geq 100 \mathrm{pg} / \mathrm{ml}$.

De acordo com Dalstein et al. ${ }^{(5)}$ a persistência de carga viral superior a $100 \mathrm{pg} / \mathrm{ml}$ está diretamente relacionada com o risco para $\mathrm{NIC} \mathrm{II/III}{ }^{(5)}$.

\section{Análise estatística}

Essa análise determinou a sensibilidade e a especificidade dos métodos citológico convencional e do DNA-Citoliq (Digene), comparando-os com o método de $\mathrm{CH}$ II para DNA/HPV de alto risco (grupo B).

\section{Resultados}

Foram analisadas 982 amostras cervicovaginais, 877 $(89,3 \%)$ pelo método convencional e $105(10,7 \%)$ pelo DNA-Citoliq. A média de idade das mulheres foi de 41,5 anos, variando de 16 a 67 anos. Trezentas e quatorze lâminas (32\%) apresentaram resultado citológico negativo, sendo 256 pelo método convencional e 58 pelo DNA-Citoliq. Dessas, 226 (72\%) mantiveram resultados negativos por $\mathrm{CH}$ para DNA/HPV de alto risco. Duzentas e sessenta e uma amostras (26,6\%) foram diagnosticadas como ASCUS no exame citológico: 236 pelo método convencional e 25 pelo DNA-Citoliq.

Das 261 amostras diagnosticadas como ASCUS, 113 $(43,3 \%)$ apresentaram resultado negativo na $\mathrm{CH}$ II para HPV de alto risco, e $148(56,7 \%)$ resultado positivo (>1 $\mathrm{pg} / \mathrm{ml})$, destas $59(39,9 \%)$ com carga viral superior ou igual a 100,0 pg/mL (Tabela 1). Duzentas e dez amostras $(21,4 \%)$ foram diagnosticadas como NIC I. Dessas 152 $(72,4 \%)$ apresentaram resultado positivo por $\mathrm{CH}$ para HPV de alto risco. Das amostras diagnosticadas como NIC I e confirmadas por $\mathrm{CH}, 101$ (66,4\%) apresentaram carga viral $\geq 100$ pg/ml. Foram diagnosticadas 197 (20,6\%) amostras como NIC II ou III, confirmando-se a presença de HPV de alto risco por $\mathrm{CH}$ II em apenas $86(43,6 \%)$. Contudo, dessas amostras, $53(61,6 \%)$ apresentaram carga viral $\geq$ $100 \mathrm{pg} / \mathrm{ml}$ (Tabela 1).

Determinaram-se a sensibilidade e a especificidade de ambos os métodos utilizados para triagem no diagnóstico de NIC II ou III, adotando-se como referência os resultados obtidos por CH II (versão 1). Observou-se que a citologia convencional apresentou sensibilidade e especificidade de $42 \%$ e $71 \%$, respectivamente. O método DNA-Citoliq apresentou elevada especificidade $(75,9 \%)$ e sensibilidade (66\%) para o diagnóstico de NIC II ou III, quando em comparação com o método convencional (Tabela 2).

\begin{tabular}{|c|c|c|c|c|c|c|c|c|c|}
\hline \multicolumn{2}{|c|}{$\begin{array}{c}\text { Diagnóstico citológico } \\
(n)\end{array}$} & \multicolumn{2}{|c|}{$\begin{array}{c}\text { CH negativa } \\
(\%)\end{array}$} & \multicolumn{2}{|c|}{$\begin{array}{l}\text { CH positiva } \\
(\%)\end{array}$} & \multicolumn{2}{|c|}{$\begin{array}{c}\text { CH positiva: carga } \\
\text { viral }<100 \mathrm{pg} / \mathrm{ml}(\%)\end{array}$} & \multicolumn{2}{|c|}{$\begin{array}{c}\text { CH positiva: carga } \\
\text { viral } \geq 100 \mathrm{pg} / \mathrm{ml}(\%)\end{array}$} \\
\hline $\begin{array}{c}\text { Conven- } \\
\text { cional } \\
(877)\end{array}$ & $\begin{array}{l}\text { DNA- } \\
\text { Citoliq } \\
(105)\end{array}$ & $\begin{array}{c}\text { Conven- } \\
\text { cional } \\
\text { (51) }\end{array}$ & $\begin{array}{l}\text { DNA- } \\
\text { Citoliq } \\
(58,1)\end{array}$ & $\begin{array}{c}\text { Conven- } \\
\text { cional } \\
(49)\end{array}$ & $\begin{array}{l}\text { DNA- } \\
\text { Ctoliq } \\
(41,9)\end{array}$ & $\begin{array}{c}\text { Conven- } \\
\text { cional } \\
(22,8)\end{array}$ & $\begin{array}{l}\text { DNA- } \\
\text { Citoliq } \\
(23,8)\end{array}$ & $\begin{array}{c}\text { Conven- } \\
\text { cional } \\
(26,2)\end{array}$ & $\begin{array}{l}\text { DNA- } \\
\text { Citoliq } \\
(18,1)\end{array}$ \\
\hline $\begin{array}{l}\text { Negativa } \\
(256)\end{array}$ & $\begin{array}{l}\text { Negativa } \\
\quad(58)\end{array}$ & $\begin{array}{c}182 \\
(71,1)\end{array}$ & $\begin{array}{c}44 \\
(75,9)\end{array}$ & $\begin{array}{c}74 \\
(28,9)\end{array}$ & $\begin{array}{c}14 \\
(24,1)\end{array}$ & $\begin{array}{c}40 \\
(15,6)\end{array}$ & $\begin{array}{c}12 \\
(20,7)\end{array}$ & $\begin{array}{c}34 \\
(13,3)\end{array}$ & $\begin{array}{c}2 \\
(3,4)\end{array}$ \\
\hline $\begin{array}{l}\text { ASCUS } \\
(236)\end{array}$ & $\begin{array}{l}\text { ASCUS } \\
(25)\end{array}$ & $\begin{array}{c}101 \\
(42,8)\end{array}$ & $\begin{array}{c}12 \\
(48)\end{array}$ & $\begin{array}{c}135 \\
(57,2)\end{array}$ & $\begin{array}{l}13 \\
(52)\end{array}$ & $\begin{array}{c}83 \\
(35,2)\end{array}$ & $\begin{array}{c}6 \\
(24)\end{array}$ & $\begin{array}{c}52 \\
(22)\end{array}$ & $\begin{array}{c}7 \\
(28)\end{array}$ \\
\hline $\begin{array}{l}\text { NIC I } \\
(200)\end{array}$ & $\begin{array}{r}\text { NIC I } \\
(10)\end{array}$ & $\begin{array}{c}57 \\
(28,5)\end{array}$ & $\begin{array}{c}1 \\
(10)\end{array}$ & $\begin{array}{c}143 \\
(71,5)\end{array}$ & $\begin{array}{c}9 \\
(90)\end{array}$ & $\begin{array}{l}48 \\
(24)\end{array}$ & $\begin{array}{c}3 \\
(30)\end{array}$ & $\begin{array}{c}95 \\
(47,5)\end{array}$ & $\begin{array}{c}6 \\
(60)\end{array}$ \\
\hline $\begin{array}{l}\text { NIC II ou } \\
\text { III (185) }\end{array}$ & $\begin{array}{l}\text { NIC II ou } \\
\text { III (12) }\end{array}$ & $\begin{array}{c}107 \\
(57,8)\end{array}$ & $\begin{array}{c}4 \\
(33,4)\end{array}$ & $\begin{array}{c}78 \\
(42,2)\end{array}$ & $\begin{array}{c}8 \\
(66,6)\end{array}$ & $\begin{array}{c}29 \\
(15,7)\end{array}$ & $\begin{array}{c}4 \\
(33,3)\end{array}$ & $\begin{array}{c}49 \\
(26,5)\end{array}$ & $\begin{array}{c}4 \\
(33,3)\end{array}$ \\
\hline
\end{tabular}

ASCUS: células escamosas atípicas de significado indeterminado; CH: captura híbrida; NIC: neoplasia intra-epitelial cervical. 


\begin{tabular}{lccc} 
Tabela 2 & \multicolumn{2}{c}{$\begin{array}{c}\text { Comparação entre sensibilidade especificidade do método citológico convencional e do DNA-Citoliq } \\
\text { para diagnóstico de NIC II ou III (casos confirmados por CH II para DNA/HPV de alto risco) }\end{array}$} \\
\hline Método & Sensibilidade para NIC II/III & Especificidade para NIC II/III \\
\hline Citologia convencional & $42 \%$ & $71 \%$ \\
DNA-Citoliq & $66 \%$ & $76 \%$ \\
\hline
\end{tabular}

CH: captura híbrida; NIC: neoplasia intra-epitelial cervical.

\section{Discussão}

Devido à forte associação entre HPV de alto risco ou oncogênico e lesões intra-epiteliais escamosas, o teste molecular de $\mathrm{CH}$ tem sido investigado em numerosos estudos, com objetivo de garantir sua utilização como coadjuvante na interpretação do diagnóstico citológico ${ }^{(2,11,16,)}$.

Observou-se que, das 314 amostras com resultados negativos pelos métodos citológicos, 88 (28\%) apresentaram resultados positivos por CH II. Dessas, apenas 36 (40,9\%) possuíam carga viral $\geq 100 \mathrm{pg} / \mathrm{ml}$. Resultados como esses, discordantes entre os métodos citológicos e moleculares, podem ocorrer devido à dificuldade do observador para interpretar a lâmina, a problemas na coleta ou ainda em razão da elevada sensibilidade do método molecular.

Segundo Castle et al. ${ }^{(3)}$, 15\% das mulheres submetidas ao teste Papanicolaou podem apresentar resultado citológico negativo, com $\mathrm{CH}$ positiva para HPV de alto risco. Em nosso estudo, observamos esse perfil em $9 \%$ das mulheres analisadas. Portanto, é importante destacar que mulheres com resultados citológico e molecular $(\mathrm{CH}$ II) negativos apresentam risco reduzido de desenvolver lesões de alto $\mathrm{grau}^{(3)}$.

Nossos resultados demonstram que 148 (56,7\%) dos $261(26,6 \%)$ casos diagnosticados como ASCUS foram positivos para HPV de alto risco no método molecular. Desses, apenas $59(39,9 \%)$ apresentaram carga viral $\geq 100$ $\mathrm{pg} / \mathrm{ml}$. Nesses casos houve predomínio de carga viral < $100 \mathrm{pg} / \mathrm{ml}, 89(60,1 \%)$ casos, o que sugere a possibilidade de reação inespecífica na $\mathrm{CH}$ II e, conseqüentemente, risco diminuído para qualquer tipo de lesão de alto grau nessas mulheres.

De acordo com a padronização do teste CH II (versão 1) pelo fabricante (Digene), as amostras com valor de RLU $\geq 1$ $\mathrm{pg} / \mathrm{ml}$ devem ser consideradas positivas. No entanto, alguns estudos demonstram que o teste teria maior especificidade se o valor de corte estivesse ao redor de 15,56 pg/ml, tornando-o ideal para a detecção de lesões intra-epiteliais e câncer, diminuindo assim a possibilidade de resultados falso-positivos, principalmente em amostras com carga viral $<100 \mathrm{pg} / \mathrm{ml}^{(7,10,16)}$. Portanto, nossas análises indicam que em exames com resultados discordantes, com carga viral $<100 \mathrm{pg} / \mathrm{ml}$, o teste molecular deve ser repetido (com nova amostra) para confirmação diagnóstica.

Entre os $210(21,4 \%)$ casos diagnosticados como NIC I, $152(72,4 \%)$ foram confirmados por $\mathrm{CH}$ II para HPV de alto risco, e $101(66,4 \%)$ apresentaram carga viral $\geq 100 \mathrm{pg} / \mathrm{ml}$. Estudos recentes relataram que pacientes com carga viral persistente e $>100 \mathrm{pg} / \mathrm{ml}$ apresentaram risco aumentado de progressão para NIC II ou III em um curto intervalo de tempo, mesmo na ausência de alterações citológicas detectáveis. No entanto, nos casos com resultado positivo pela $\mathrm{CH}$ II, mas com carga viral < 100 $\mathrm{pg} / \mathrm{ml}$, há menor chance de desenvolvimento de lesões de alto grau ${ }^{(5)}$.

O diagnóstico de NIC II ou III foi confirmado pela $\mathrm{CH}$ II de alto risco em $86(43,6 \%)$ casos, entretanto, desse universo, em $53(61,6 \%)$ a carga viral detectada foi $\geq$ 100 pg/ml. O predomínio de casos com alta carga viral sugere haver uma associação entre o valor da carga viral e as lesões precursoras de câncer cervical na população estudada.

Nossos resultados confirmam estudos anteriores e indicam que essas pacientes devem ser acompanhadas com a repetição periódica do exame para monitoramento da carga viral ${ }^{(6,8)}$. No entanto, corroborando Nieminen et al. ${ }^{(12)}$, tanto os valores da carga viral como sua persistência precisam ser avaliados, juntamente com a evolução clínica.

Ao utilizar métodos distintos para triagem, observou-se que o método DNA-Citoliq apresentou maior sensibilidade e especificidade (66\% e $76 \%$ respectivamente) para detecção de lesões de alto grau, NIC II/III (Tabela 2). Outra vantagem do método DNA-Citoliq está no meio de transporte utilizado, que preserva adequadamente o DNA/HPV para detecção pela $\mathrm{CH}$ II(13). O teste de DNA/HPV 
no volume residual da amostra de citologia líquida está sendo cada vez mais utilizado clinicamente para orientar o seguimento de mulheres com resultados citológicos inespecíficos (ASCUS), principalmente por diminuir o número de coletas cervicovaginais na mesma paciente.

Estudos realizados em nosso laboratório demonstraram que a citologia em base líquida (DNA-Citoliq) é extremamente eficaz para esclarecimento de casos onde o diagnóstico inicial é de ASCUS, permitindo a repetição ou diluição da amostra para conclusão diagnóstica (dados não publicados). No entanto, nessa metodologia, a padronização de leitura é difícil e, embora o sistema DNA-Citoliq represente um avanço tecnológico para o diagnóstico citopatológico, a transição entre os métodos deve ser realizada com cautela e após extensiva padronização técnica.

Portanto, conclui-se que na população estudada há uma clara associação entre o valor da carga viral, determinada pelo método de CH II (versão 1), e o grau das lesões precursoras de câncer cervical diagnosticadas tanto pelo método citológico convencional como em base líquida (DNA-Citoliq). Pacientes com carga viral > 100 $\mu \mathrm{g} / \mathrm{ml}$ devem ser monitoradas periodicamente, já que a persistência da alta carga viral está relacionada com pior prognóstico.

\section{Referências}

I. AQUILAR, P. et al. Factors associated with Mexican women's familiarity with the purpose of the pap test. Bull of the Pan American Health Organization, v. 30, p. 348-53, 1996.

2. CARVALHO, M. et al. Braz J Infect Dis, v. 7, p. I-8, 2003.

3. CASTLE, P.E. et al. Absolute risk of a subsequent abnormal pap among oncogenic human papillomavirus DNA-positive, cytologically negative women. Cancer, v. 95, n. I0, p. 21455I, 2002.

4. CASTLE, P.E. et al. Results of human papillomavirus DNA testing with the hybrid capture 2 essay are reproductible. J Clin. Microbiol, v. 40, p. 1088-90, 2002.

5. DALSTEIN, $\vee$. et al. Persistence and load of high-risk HPV are predictors for development of high-grade cervical lesions: a longitudinal French cohort study. Int J Cancer, v. 106, p. 396-403, 2003.

6. FAIT, G. et al. Contribution of human papillomavirus testing by hybrid capture in the triage of women with repeated abnormal Pap smears before colposcopy referral. Gynecology Oncol, v. 79, p. 177-80, 2000

7. FEDERSCHNEIDER, J.M. et al.The borderline or weakly positive hybrid capture II HPV test: a statistical and comparative (PCR) analysis. Am J Obstet Gynecol, v. 191, n. 3, p. 757-61, 2004.

8. HERNANDEZ-HERNANDEZ, D.M. et al. Association between high-risk human papillomavirus DNA load and precursor lesions of cervical cancer in Mexican women. Gynecol Oncol, v. 90, p. 310-7, 2003

9. HO, G.Y.F.; BIERMAN, R.; BEARDSLEY, L. Natural history of cervicovaginal papillomavirus infection in young women. New Engl J Med, v. 338, p. 423-8, 1998.
10. HOWARD, M.; SELLORS, J:; KACZOROWSKI, J. Optimizing the hybrid capture II human papillomavirus test to detect cervical intraepithelial neoplasia. Obstetrics \& Gynecology, v. I00, p. 972-80, 2002

I I. KUNZ, J. et al. Comparison of conventional Pap smears with thin layer specin (liquid-based Pap test) and correlation with cytopathological findings with HPV status using the hybrid capture system. Schweiz Rundsch Med Prax, v. 21, n. 87, p. 1434-40, 1998

12. NIEMINEN, P.et al. Comparison of HPV test versus conventional and automation-assisted Pap screening as potential tools for preventing cervical cancer. BJOG, v. I I I, p. 842-8, 2004

13. NONOGAKI, S. et al. Hybrid capture II and polymerase chain reaction for identifying HPV infections in samples collected in a new collection medium: one comparison. Acta Cytol, v. 48, n. 4, p. 5I4-20, 2004.

I4. PINTO, A.P.; TULIO, S.; CRUZ, R.O. Co-fatores do HPV na oncogênese cervical. Rev Assoc Med Bras, v. 48, n. I, p. 73-8, 2002.

15. ROWE L.R.; ALDEEN,W.; BENTZ, J.S. Prevalence and typing of HPV DNA by hybrid capture II in women with ASCUS,ASCH, LSIL and AGC on ThinPrep Pap test. Diagn Cytopathol, v. 30, n. 6, p. 426-32, 2004.

16. SCHIFFMAN, M. et al. HPV DNA testing in cervical cancer screening results from women in high-risk province Costa Rica.JAMA, v. 283, p. 87-93, 2000.

17. SILVA, A.; LONGATTO, A. Colo uterino e vagina. Revinter, 2000.

18.VINCE, A. et al. Clinical utility of molecular detection of human papillomavirus in cervical samples by hybrid capture technology.J Clin Virol, v. 25, p. S109-12, 2002. 